\title{
Korelasi antara Sikap terhadap Perbedaan Kultur dengan Intensi Turnover pada Karyawan Perusahaan X
}

\author{
Tiara Fabrikasi ${ }^{*}$ \\ Fakultas Psikologi Universitas Kristen Satya Wacana \\ Berta Esti Ari Prasetya \\ Fakultas Psikologi Universitas Kristen Satya Wacana
}

\begin{abstract}
This study aims to determine the correlation between attitudes toward cultural differences with turnover intention in employees company $X$. the hypothesis in this study there is significant negative relation between attitudes toward cultural differences and turnover intention in employees company $X$. the subject in this studying were 55 employees from company X. The data obtained using aattitudes toward cultural difference scale and a scale of turnover intention. The result showed a value of $\rho=-0.738$ with $p=0.000(p<0.05)$. Thus, it can be concluded that there is a significant negative correlation between attitudes toward cultural differences and turnover intention in employee company X. So, the hypothesis proposed in this study can be accepted.
\end{abstract}

Keywords: attitudes toward cultural differences, turnover intention, employees of company $x$

Abstrak.Penelitian ini bertujuan untuk mengetahui korelasi antara sikap terhadap perbedaan kultur dengan intensi turnover terhadap karyawan perusahaan X. Hipotesis dalam penelitian ini adalah terdapat hubungan negatif yang signifikan antara sikap terhadap perbedaan kultur dan intensi turnover. Subjek dalam penelitian ini adalah 55 karyawan perusahaan X. Data yang diperoleh menggunakan skala sikap terhadap perbedaan kultur dan intensi turnover. Hasil penelitian menunjukan nilai $\rho=-0.738$ dengan $p=0.000(p<0.05)$. Dengan hasil tersebut dapat disimpulkan terdapat korelasi negatif yang signifikan antara sikap terhadap perbedaan kultur dan intensi turnover pada karyawan perusahaan X. Sehingga, hipotesis yang diajukan dalam penelitian ini dapat diterima.

Kata kunci: sikap terhadap perbedaan kultur; intensi turnover; karyawan perusahaan $x$

\footnotetext{
${ }^{1}$ Korespondensi Tiara Fabrikasi. Fakultas Psikologi Universitas Kristen Satya Wacana, J1. Diponegoro No.5260, Salatiga, Kec. Sidorejo, Kota Salatiga, Jawa Tengah, 50711. Email: tiara.fabrikasi99@gmail.com
} 
Perusahan merupakan suatu organisasi yang menghasilkan barang dan jasa untuk mendapatkan laba (Ebert \& Griffin, 2011). Keberhasilan suatu perusahaan untuk mencapai tujuannya jelas dipengaruhi oleh karyawan yang bekerja didalamnya. Maka dari itu karyawan merupakan aspek terpenting dalam kegiatan usaha apapun karena karyawan merupakan representatif dari sebuah perusahaan. Kinerja suatu perusahaan sangat ditentukan oleh kondisi dan perilaku karyawannya (Toly, 2001). Karyawan yang bekerja pada perusahaan tidak dapat disamaratakan jumlah dan kebudayaannya, semua bergantung pada kebutuhan perusahaan. Oleh karena itu perusahaan menjadi tempat yang kompleks, dimana terdiri dari banyak karyawan yang beragam kebudayaannya.

Di Indonesia ada sekitar 10\%-12\% karyawan yang melakukan turnover setiap tahunnya (Putra \& Prihatsanti, 2016). Untuk intensi turnover sendiri, data menurut Survei Global Workforce Study tahun 2012 yang dilakukan oleh Watson dengan melibatkan 1005 karyawan di Indonesia, 27\% diantaranya dalam dua tahun mendatang yaitu tahun 2014 kemungkinan besar akan meninggalkan pekerjaannya saat ini dan sebanyak $42 \%$ karyawan juga akan meninggalkan perusahaan mereka sekarang untuk meningkatkan karirnya di masa depan (Rachmata dan Kubatini, 2018). Proses turnover didasari oleh kondisi karyawan yang memiliki keinginan untuk meninggalkan organisasi atau biasa disebut intensi turnover (Widjaja, 2006).

Berdasarkan wawancara yang sudah dilakukan terhadap X pada 6 Juni 2020 yang berdomisili di Bandung dan bekerja pada salah satu bank swasta, juga melakukan wawancara terhadap Y pada 9 Juni 2020 yang berdomisili di Yogyakarta dan bekerja di salah satu LSM, terakhir melakukan wawancara kepada $\mathrm{Z}$ pada 27 Mei 2020 yang berdomisili di Bali dan bekerja pada salah satu perusahaan fashion. Ketiga responden ini mengatakan bahwa keinginan untuk mengundurkan diri (intensi turnover) disebabkan oleh ketidaknyamanan terhadap rekan sekerja juga terhadap atasan.

Intensi turnover merupakan keinginan individu secara sadar dan disengaja untuk meninggalkan organisasi (Roodt, 2012). Chen (2010) mengatakan bahwa intensi turnover merupakan masalah penting untuk memanajemen selama bertahuntahun. Jika tidak segera ditangani akan berdampak pada tingginya turnover $\mathrm{di}$ perusahaan. Menurut Huning (2011), di dalam suatu perusahaan adanya pergantian karyawan karena ada yang mengundurkan diri sangat merugikan. Hal tersebut menyebabkan akan adanya pengeluaran yang cukup besar, bukan hanya itu saja namun juga adanya gangguan kerja, hilangnya pengetahuan, memori organisasi dan keterampilan.

Intensi turnover dipengaruhi oleh beberapa faktor. Menurut Mathis (2001) ada beberapa hal yang menjadi penentu intensi turnover, yaitu komponen organisasional, hubungan karyawan, peluang karir, penghargaan, serta rancangan tugas dan pekerjaan. Dalam penelitian ini penulis berfokus pada hubungan karyawan. Hubungan karyawan terdiri dari dua aspek, salah satunya adalah hubungan antar rekan kerja. Hubungan antar rekan kerja ini dipengaruhi oleh sikap karyawan terhadap karyawan lainnya. Oleh karena itu, penulis fokus pada hubungan karyawan yang memicu terjadinya intensi turnover. Dikarenakan ketidaknyamanan atas sikap rekan kerja dapat menyebabkan intensi turnover dalam karyawan.

Sikap itu sendiri adalah penentu utama bagi perilaku (tindakan) sehari-hari, walaupun ada faktor lainnya yaitu lingkungan dan keyakinan seseorang (Zuchdi, 1995). Ajzen (1980) mengatakan sikap sebagai kecenderungan untuk merespon sesuatu hal secara konsisten 
untuk menyatakan setuju atau tidak setuju dengan memperhatikan suatu objek tertentu. Secara struktur sikap terdiri atas tiga komponen yaitu kognitif, afektif, dan konatif. Azwar (2012) menjelaskan bahwa komponen kognitif merupakan apa yang dipercayai oleh seseorang, lalu komponen afektif berhubungan dengan perasaan yang berkaitan dengan aspek emosional, dan terakhir komponen konatif berkaitan dengan aspek kecenderungan berperilaku sesuai dengan sikap yang dimiliki seseorang.

Dalam penelitiannya Schiefer (2013) mengatakan bahwa sikap individu terhadap orang lain dibentuk oleh lingkungan budaya dimana individu tersebut banyak menghabiskan waktunya. Budaya adalah seluruh sistem gagasan, tindakan, dan hasil karya manusia dalam rangka kehidupan masyarakat yang dimiliki manusia dengan belajar (Koentjaraningrat, 2009). Nilai dalam budaya itu sendiri mewakili hal secara implisit dan eksplisit yang berkaitan dengan ide abstrak tentang apa yang baik, benar dan diinginkan oleh masyarakat. Adanya perbedaan sikap di masyarakat salah satunya dipengaruhi oleh adanya perbedaan kultur atau budaya (Schiefer, 2013), maka dari itu dapat dikatakan bahwa sikap masing-masing individu dipengaruhi oleh perbedaan kultur atau multikultural.

Sikap terhadap perbedaan kultur itu sendiri adalah kecenderungan individu untuk menerima atau tidak menerima individu lainnya pada suatu lingkungan sosial yang memiliki kultur beragam atau kultur yang berbeda- beda. (Fuertes, 2000). Jadi dapat dikatakan bahwa sikap terhadap perbedaan kultur adalah bagaimana individu dapat menerima atau tidak menerima adanya perbedaan atau keberagaman kultur pada individu lain di dalam suatu lingkungan sosial. Dimana hal ini dapat diukur melalui tiga aspek yaitu diversity of contact, relativistic application, dan sense of connection (Fuertes, 2000). Diversity of contact itu sendiri menjelaskan tingkat keterikatan atau kecenderungan individu untuk berinteraksi dengan lingkungan sosial yang memiliki keberagaman serta keikutsertaan individu dalam kegiatan lintas budaya. Relativistic application, aspek ini melihat sejauh mana individu mengakui, memberi nilai, dan menerima adanya persamaan dan perbedaan antar individu. Comfort with differences, aspek ini menjelaskan bagaimana individu merasa terhubung dengan individu lainnya karena ada persamaan pengalaman. Aspek ini lebih menunjukan individu yang dapat merasa nyaman dengan gagasan atau berinteraksi dengan lingkungan sosial yang memiliki beragam budaya.

Dimana sikap merupakan afek atau penilaian positif dan negatif terhadap suatu objek. Begitupun pada saat berada di tempat kerja, sikaplah yang menjadi penentu dalam berperilaku. Sikap positif menggambarkan rasa senang sedangkan sikap negatif menggambarkan rasa kegelisahan dan ketidaknyamanan (Zuchdi,1995). Sikap positif karyawan terhadap perbedaan kultur dalam organisasi memperlihatkan kemauan untuk mempelajari perbedaan tersebut, mau berinteraksi dengan karyawan lain yang berbeda latar belakang, lalu melihat perbedaan kultur ini sebagai sebuah keuntungan bagi dirinya dan juga organisasi (Hostager dkk, 2001). Lalu menurut Hamamura (2016), sikap karyawan terhadap perbedaan kultur akan menunjukan adanya penerimaan terhadap kelompok sosial lainnya. Sikap positif karyawan terhadap perbedaan kultur juga diperlihatkan melalui sikap mempertahankan identitas sendiri namun juga mau berinteraksi secara bebas atau leluasa dengan karyawan lainnya yang berbeda kultur (Jackson dkk, 2018). Sedangkan sikap negatif karyawan terhadap perbedaan kultur itu sendiri ditunjukan melalui adanya rasisme, diskriminasi, dan tuntutan untuk 
mengucilkan satu sama lain (Jackson, 2018). Menurut Mayo dkk (2016) sikap negatif karyawan terhadap keberagaman kultur dapat terlihat dari adanya penurunan kinerja karyawan, yang berpengaruh pada efektivitas tim itu sendiri (Schuster dkk, 2014). Menurut Miville dkk (1999) sikap negatif terhadap keberagaman kultur akan memicu individu untuk tidak mau berinteraksi dengan kelompok sosial lainnya yang memiliki perbedaan kultur.

Sikap negatif karyawan terhadap perbedaan kultur ini lah yang dapat memicu intensi turnover. Hal ini didukung oleh penelitian sebelumnya yang dilakukan oleh Jeong dan Baek (2016). Dimana hasilnya menunjukan hubungan signifikan yang negatif antara sikap terhadap keberagaman dan intensi turnover. Jika hal ini tidak segera ditangani maka akan menimbulkan dampak yang besar bagi karyawan itu sendiri maupun perusahaan. Maka dari itu, peneliti tertarik untuk melakukan penelitian ini dengan hipotesis yang diajukan adalah terdapat korelasi negatif antara sikap terhadap perbedaan kultur dengan intensi turnover. Tujuan dari penelitian ini adalah untuk mengetahui hubungan antara sikap terhadap perbedaan kultur dan intensi turnover pada karyawan.

\section{METODE}

Penelitian ini menggunakan dua variabel yaitu sikap terhadap perbedaan kultur yang merupakan variabel X (variabel bebas) dan intensi turnover yang merupakan variabel Y (variabel terikat). Sikap terhadap perbedaan kultur adalah respon individu terkait menerima atau tidak menerima adanya perbedaan kultur atau budaya di dalam suatu lingkungan. Semakin tinggi skor maka semakin individu tersebut dapat menerima adanya perbedaan, namun semakin rendah skor semakin individu tersebut tidak dapat menerima adanya perbedaan.
Intensi turnover adalah keinginan individu untuk mengundurkan diri/ resign dari suatu perusahaan. Semakin tinggi skor maka semakin tinggi juga intensi turnover pada karyawan, namun semakin rendah skor maka semakin rendah pula intensi turnover pada karyawan.

Penelitian ini menggunakan pendekatan kuantitatif. Pendekatan kuantitatif yang menekankan pada data numerik dan diolah secara statistika (Azwar, 2012). Penelitian ini menggunakan metode korelasional. Penelitian ini digunakan untuk mengetahui apakah ada hubungan negatif yang signifikan antara sikap terhadap perbedaan kultur dan intensi turnover.

Populasi dalam penelitian ini adalah karyawan backoffice PT. X yang berjumlah 55 karyawan yang berasal dari berbagai daerah yaitu Jakarta, Bandung, Solo, Medan, Yogyakarta, Bogor, Palangkaraya, dan Salatiga. Sampel pada penelitian ini adalah seluruh karyawan back office sebanyak 55 karyawan. Menurut Sugiyono (2008), jumlah sampel jenuh adalah total dari keseluruhan populasi atau dalam hal ini adalah karyawan.

Dalam penelitian ini, peneliti membagikan kuesioner kepada partisipan dengan menggunakan 2 skala pengukuran yang terdiri atas sikap terhadap perbedaan kultur dan intensi turnover. Dimana skala yang digunakan merupakan hasil terjemahan dari penelitian sebelumnya. Dalam skala tersebut terdapat enam aitem favorable dan delapan aitem unfavorable. Kedua skala ini memiliki empat pilihan jawaban yaitu sangat setuju (SS), setuju (S), tidak setuju (TS), dan sangat tidak setuju (STS).

Untuk mengukur variabel sikap terhadap perbedaan kultur, alat ukur yang dibuat berdasarkan aspek yang dikemukakan oleh Fuertes (2000). Perhitungan uji daya diskriminasi aitem ini dilakukan 2 kali 
putaran menggunakan SPSS 21 windows version dengan standar corrected itemtotal correlation $\geq 0.3$. Hasil yang diperoleh menyisakan 36 dari 45 aitem yang ada dengan tingkat reliabilitas sebesar 0.963 dan tergolong ke dalam standar yang reliabel.

Untuk mengukur variabel turnover intention, alat ukur yang digunakan berdasar pada aspek yang dikemukakan oleh Roodt pada tahun 2007. Perhitungan uji daya diskriminasi aitem ini dilakukan 2 kali putaran menggunakan SPSS dengan standar corrected item-total correlation $\geq$ 0.3 . Hasil yang diperoleh menyisakan 9 dari 14 aitem yang ada dengan tingkat reliabilitas sebesar 0.783 dan tergolong ke dalam standar reliabel.

Dalam pengujian hipotesis, peneliti menggunakan Teknik korelasional non parametric spearman yang merupakan uji satistik untuk mengetahui hubungan 2 (dua) variabel dengan skala ordinal.

\section{HASIL DAN DISKUSI}

Pada penelitian ini dilakukan uji asumsi dengan menggunakan uji normalitas. Uji normalitas dilakukan pada kedua variabel menggunakan

Klomogorov-Smirnov dengan bantuan program SPSS.

Tabel 1.

Hasil Uji Normalitas

\begin{tabular}{lll}
\hline Variabel & $\begin{array}{l}\text { Nilai } \\
\text { Signifikansi }\end{array}$ & Keterangan \\
\hline Sikap & 0.397 & Normal \\
Terhadap & & \\
Perbedaan & & \\
Kultur & & \\
\hline Intensi & 0.827 & Normal \\
Turnover & & \\
\hline
\end{tabular}

Dari tabel diatas disimpulkan bahwa uji normalitas berdistribusi normal dengan nilai signifikansi diatas 0.05 yaitu 0.397 untuk variabel sikap terhadap perbedaan kultur dan 0.827 untuk variabel intensi turnover.

Berdasarkan uji normalitas yang telah, didapatkan hasil bahwa penelitian ini berdistribusi normal, maka dapat dilakukan uji korelasi menggunakan spearman.

Tabel 2.

Hasil Uji Korelasi

\begin{tabular}{lll}
\hline Hipotesis & $\begin{array}{l}\text { Nilai Uji } \\
\text { Statistika }\end{array}$ & Keterangan \\
\hline Hubungan & $\rho=-0.738 ;$ & Hipotesis \\
negatif & $\mathrm{p}=0.000$ & Diterima \\
antara & $(\mathrm{p}=<0.05)$ & \\
sikap & & \\
terhadap & & \\
perbedaan & & \\
kultur dan & & \\
intensi & & \\
turnover & & \\
\hline
\end{tabular}

Uji korelasi yang telah dilakukan pada tabel antara sikap terhadap perbedaan kultur dan intensi turnover menunjukan hasil bahwa adanya hubungan negatif antara sikap terhadap perbedaan kultur dan intensi turnover dengan hasil uji statistik $\mathrm{r}=-0.738 ; \mathrm{p}=0.000 \quad(\mathrm{p}<0.05)$. Berdasarkan hasil tersebut dapat dikatakan bahwa hipotesis dapat diterima dengan kata lain adanya korelasi antara sikap terhadap perbedaan kultur dengan intensi turnover pada karyawan perusahaan $\mathrm{X}$.

Dalam penelitian ini, penulis mengajukan hipotesis korelasi antara sikap terhadap perbedaan kultur dengan intensi turnover. Berdasarkan hasil uji korelasi pada kedua variabel, menunjukan koefisien korelasi $r$ $=-0.738$ yang berarti bahwa adanya hubungan negatif yang signifikan antara sikap terhadap perbedaan kultur dengan intensi turnover pada karyawan perusahaan $\mathrm{X}$, sehingga dapat dikatakan bahwa hipotesis $\mathrm{H}_{1}$ diterima dan $\mathrm{H}_{0}$ ditolak. Dengan semakin rendah sikap 
terhadap perbedaan kultur maka semakin tinggi intensi turnover pada karyawan.

Hasil penelitian ini sejalan dengan hasil penelitian Jeong \& Baek (2016) dimana terdapat hubungan signifikan negatif antara sikap terhadap keberagaman kultur dengan intensi turnover. Semakin negatif karyawan menyikapi perbedaan kultur maka intensi turnover semakin tinggi, sebaliknya juga semakin positif karyawan menyikapi perbedaan kultur maka intensi turnover semakin rendah.

Tinggi rendahnya intensi turnover pada karyawan tentunya dipengaruhi oleh beberapa faktor, salah satunya adalah sikap terhadap perbedaan kultur. Hal ini sesuai dengan yang dikatakan oleh Jeong \& Baek (2016) yaitu, sikap negatif karyawan pada perbedaan kultur memicu adanya intensi turnover itu sendiri. Dalam penelitian tersebut dijelaskan bahwa sikap karyawan pada perbedaan kultur yang ada di dalam lingkungan kantor berkorelasi terhadap intensi turnover. Intensi turnover itu sendiri merupakan keinginan karyawan untuk mengundurkan diri dari suatu perusahaan. Sikap negatif karyawan terhadap perbedaan kultur memicu karyawan untuk tidak mau berinteraksi dengan kelompok sosial lainnya atau kultur lainnya (Miville dkk, 1999). Menurut Cox dan Blake (1991), ketidakinginan karyawan untuk berinteraksi dengan karyawan lainnya yang diakibatkan oleh perbedaan kultur akan mengganggu komunikasi antar karyawan itu sendiri yang pada akhirnya mengakibatkan tingginya intensi turnover pada suatu perusahaan. Hal ini sesuai dengan hasil kategorisasi pada penelitian ini.

Sikap positif terhadap perbedaan kultur menurut Hamamura (2016), diperlihatkan melalui sikap karyawan yaitu adanya penerimaan terhadap kelompok sosial lainnya. Sikap positif karyawan terhadap perbedaan kultur dalam organisasi memperlihatkan kemauan untuk mempelajari perbedaan tersebut, mau berinteraksi dengan karyawan lain yang berbeda latar belakang, lalu melihat perbedaan kultur ini sebagai sebuah keuntungan bagi dirinya dan juga organisasi (Hostager dkk, 2001). Menurut penelitian Jeong \& Baek (2016), sikap positif ini tidak memicu adanya intensi turnover. Sedangkan sikap negatif karyawan terhadap perbedaan kultur itu sendiri ditunjukan melalui adanya rasisme, diskriminasi, dan tuntutan untuk mengucilkan satu sama lain (Jackson, 2018). Dimana hal ini meningkatkan intensi turnover. Seperti penelitian sebelumnya yang dilakukan oleh Jeong \& Baek (2016) yang menjelaskan bahwa sikap negatif yang dimiliki karyawan terhadap perbedaan kultur yang ada di perusahaan meningkatkan keinginan karyawan untuk mengundurkan diri, hal ini dikarenakan karyawan tidak nyaman dengan karyawan lainnya yang memiliki kultur yang berbeda. Dikarenakan ketidaknyaman itulah karyawan berkeinginan untuk mengundurkan diri.

Sama halnya dengan hasil penelitian ini, dimana sikap karyawan terhadap perbedaan kultur memicu terjadinya intensi turnover. Pada skala intensi turnover subjek masuk dalam kategori tinggi dengan persentase $69 \%$ dengan nilai rata - rata 43.15, hal ini dikarenakan sebagian besar karyawan berkeinginan untuk mengundurkan diri. Keinginan untuk mengundurkan diri pada karyawan dipicu oleh sikap negatif atau rendah karyawan itu sendiri terhadap perbedaan kultur di tengah karyawan, hal ini dibuktikan oleh hasil penelitian pada skala sikap terhadap perbedaan kultur. Subjek masuk dalam kategori rendah dengan persentase $54 \%$ dengan nilai rata-rata 88.89. Rendahnya rata-rata nilai sikap terhadap perbedaan kultur dipicu oleh beberapa hal. Menurut Martin (2014) rendahnya sikap terhadap perbedaan kultur di dalam perusahaan disebabkan oleh 
adanya perbedaan norma, perbedaan opini, perbedaan tradisi, dan perbedaan nilai-nilai pada karyawan yang pada akhirnya mengganggu komunikasi antar karyawan. Hasil penelitian ini menunjukkan adanya korelasi signifikan yang negatif antara sikap terhadap perbedaan kultur dengan intensi turnover pada karyawan. Hal ini juga dibuktikan melalui sumbangan efektif sikap terhadap perbedaan kultur pada intensi turnover sebesar $58.7 \% \quad\left(\mathrm{R}^{2}=\right.$ 0.587), Sedangkan sisanya dipengaruhi oleh faktor lain sebesar $41.3 \%$. Hal ini disebabkan sebagian besar karyawan memandang perbedaan kultur di dalam karyawan merupakan faktor utama yang menyebabkan timbulnya intensi turnover. Sementara Sebagian lainnya memandang perbedaan atau persamaan kultur dalam karyawan bukanlah tolak ukur timbulnya intensi turnover. Dengan demikian sikap dengan perbedaan kultur bukanlah hal mutlak yang mempengaruhi intensi turnover melainkan terdapat faktor lain yang dapat mempengaruhinya.

Menurut Hussain \& Xian (2019) ada beberapa faktor yang dapat memengaruhi intensi turnover. Beberapa faktor tersebut adalah hubungan kolega, komitmen organisasi, keadilan organisasi, reputasi organisasi, komunikasi, dan politik organisasi. Keenam hal ini pula-lah yang memiliki kemungkinan besar dalam memengaruhi intensi turnover.

\section{SIMPULAN}

Kesimpulan dari penelitian ini adalah adanya korelasi antara sikap terhadap perbedaan kultur dan intensi turnover pada karyawan perusahaan $X \quad(\rho=-0.738$; $\mathrm{p}=0.000 \quad(\mathrm{p}<0.05))$ dengan sumbangan efektif sebesar $58.7 \%$.

\section{SARAN}

Dalam penelitian ini ditemukan adanya korelasi antara sikap terhadap perbedaan kultur dengan intensi turnover pada karyawan. Sikap negatif terhadap perbedaan kultur di dalam perusahaan dapat diminimalisir dengan berbagai cara salah satunya adalah pengenalan multikultural itu sendiri melalui kegiatankegiatan yang mengenalkan keragaman budaya seperti gathering yang bertemakan kebudayaan.

Karyawan diharapkan dapat memanfaatkan setiap kesempatan yang ada untuk mengenal berbagai kultur terutama kultur pada setiap karyawan, guna untuk meningkatkan rasa saling menghargai dan menghormati satu sama lain.

Penelitian selanjutnya diharapkan bisa menambahkan variabel seperti faktorfaktor lainnya yang memengaruhi intensi turnover seperti hubungan kolega, komitmen organisasi, keadilan organisasi, reputasi organisasi, komunikasi, dan politik organisasi. Juga dapat menggunakan perusahaan lain seperti bank, perusahaan produksi, instansi pemerintahan, dan lain sebagainya. Pada penelitian selanjutnya juga diharapkan melakukan validasi alat ukur sebelum menggunakannya supaya tidak banyak aitem gugur.

\section{DAFTAR PUSTAKA}

Ajzen, I., \& Fishbein, M. (1980). Understanding attitudes and predicting social behavior. New Jersey. NJ: PrenticeHall.

Azwar, S. (2012). Metode penelitian. Yogyakarta: Pustaka Pelajar.

Bothma, F. C. \& Roodt, G. (2012). Wokdbased identity and work engagement as potential antecedent of task performance and turnover intention: Unravelling a complex relationship. SA Journal of Industrial Psychology, 38(1), 1 - 17.

Chen, M. F., Lin, C. P., \& Lien, G. Y. (2010). Modelling job stress as a mediating role in predicting turnover intention. The Service Industries Journal, 31(8), 1327 - 1345. 
Cox, T., \& Blake, S. (1991). Managing cultural diversity: Implications for organizational competitiveness. Academy of Management Executive, 5(3), 45 - 56.

De Meuse, K. P., \& Hostager, T. J. (2001). Developing an instrument for measuring attitudes toward and perceptions of workplace diversity: An initial report. Human Resource Development Quarterly, 12(1), $33-51$.

Ebert, Ronald J., \& Griffin, Ricky W. (2011). Business essentials. New Jersey. NJ: Prentice-Hall.

Fuertes, dkk. (2000). Factor structure and short form of the miville guzman universality diversify scale. Journal of Measurement and Evaluation In Counseling And Development, 33(1), 157 $-169$.

Hamamura, T. (2016). Social identity and attitudes toward cultural diversity. Journal of Cross-Cultural Psychology, 48(2), 184 $-194$.

Huning, T. M., \& Thomson, N. F. (2011). An empirical examination of the impact of performance attributions and job satisfaction on turnover intentions. Journal of Organizational Culture, Communications and Conflict, 1(1), 121 130.

Hussain, S., \& Huei Xian, S. (2019). Factors Affecting Employees' Turnover Intention in Construction Companies in Klang, Selangor. KnE Social Sciences, $3(22)$, 108-131. https://doi.org/10.18502/kss.v3i22.5047

Jackson, L. T. B., \& van de Vijver, F. J. R. (2018). Multiculturalism in the workplace: Model and test. SA Journal of Human Resource Management, 16(1), 1 - 15.
Jeong, H \& Baek, y. (2016). The effect of diversity sensitive orientation on job satisfaction and turnover intention. Journal of the Korea Academia-Industrial cooperation Society, 18(70), 569 - 578.

Koentjaraningrat. (2009). Pengantar ilmu antropologi. Jakarta: Rineka Cipta.

Martin, Gillian C. (2014). The effects of cultural diversity in the workplace. Journal of Diversity Management, 9(2), 89 $-92$.

Mathis, L. R., \& Jackson, J. H. (2001). Manajemen sumber daya manusia. Jakarta: PT. Salemba Emban Patria.

Mayo, M., Kakarika, M., Mainemelis, C., \& Deuschel, N. T. (2016). A metatheoretical framework of diversity in teams. Journal of Human Relations, 70(8). $911-939$.

Miville, dkk (1999). Appreciating similarities and valuing differences: The miville guzman universality diversity Scale. Journal of Counseling Psychology, 46(3), $291-307$.

Potter, R., Yap, K., \& Schuster, S. (2014). Self-Compassion mediates the relationship between parental criticism and social anxiety. Journal of Psychology and Psychological Therapy, 14(1), 33 - 43.

Putra, M. T. P., \& Prihatsanti, U. (2016). Hubungan antara beban kerja dengan intensi turnover pada karyawan di PT. "X". Jurnal Empati, 5(2). 303 - 307.

Rachmatan, R., \& Kubatini, S. (2018). Hubungan antara keterikatan kerja dengan intensi keluar kerja pada karyawan swalayan di Banda Aceh. Jurnal Psikogenesis, 6(1). 1 - 10.

Schiefer, D., Mollering, A., Daniel, E., Benish-Weisman, M., \& Boehnke, K. (2010). Cultural values and outgroup 
negativity: A cross-cultural analysis of early and late adolescents. European Journal of Social Psychology, 40(1). 635 651.

Schiefer, D. (2013). Culture values and group related attitudes: A comparison of individuals with and without migration background across 24 countries. Journal of Cross-Cultural Psychology, 44(2). 246 262.

Sugiyono. (2008). Metode penelitian kuantitatif kualitatif dan $r \& d$. Bandung: Alfabeta.

Toly A. A. (2001). Analisis faktor-faktor yang mempengaruhi turnover intention pada staf kantor akuntan publik. Jurnal Akuntansi dan Keuangan, 3(2). 102 - 125.

Widjaja, D. C., Margarita F, \& Fenny Kusuma D. W. (2006). Analisa persepsi employee empowerment terhadap employee turnover intention di Hotel X Kupang Nusa Tenggara. Jurnal Manajemen Perhotelan, 4(2), 72 - 83.

Zuchdi, D. 1995. Pembentukan sikap. Cakrawala Pendidikan, 3(1), 51 - 61 